\title{
1D-2D MODELING OF URBAN FLOODS AND RISK MAP GENERATION FOR THE PART OF HYDERABAD CITY
}

\author{
Rangari V A ${ }^{1, *}$, Gonugunta $\mathrm{R}^{1}$, Umamahesh $\mathrm{N} \mathrm{V}^{1}$, Patel A K ${ }^{1}$, Bhatt C M ${ }^{2}$ \\ ${ }^{1}$ Department of Civil Engineering, National Institute of Technology, Warangal, India - vinayrangari@ gmail.com, \\ ${ }^{2}$ Disaster Management Division, National Remote Sensing Center, Hyderabad, India
}

Commission V.SS: Disaster Monitoring, Damage Assessment and Risk Reduction

KEYWORDS: Stormwater, Urban Flood, Modeling, Zone XIII, SWMM, PCSWMM.

\begin{abstract}
:
Space for water is now becoming guiding principle of urban planning because urban flooding is the major problem facing by most of the cities in India. Urban development in developing countries like India usually occurs with high population concentrating in small areas, with poor drainage conditions. People occupy floodplain areas in low flood years and when larger flood occurs it causes high damage. The origin for urban floods is floodplains encroachment and unplanned drainage systems. Complexities in the urban environment and drainage infrastructure have an inherent influence on surface runoff. This runoff generates urban flooding which poses challenges to modeling urban flood hazard and risk. As like in river flooding satellite images are not available for unban flooding scenario. So better modelling provides minimizing loss of life and property. The present study focuses on recognizing the highly effected areas which are liable to flooding when extreme rainfall occurs for part of Hyderabad city (Zone XIII). The entire Hyderabad city is divided into 16 zones and each zone having details of existing drain network. A coupled 1D-2D flood modelling approach is used to identify flood prone areas and develop flood inundation and flood risk maps. 1D model for pilot area is developed using storm water management model (SWMM) and coupled with 2D PCSWMM. A web based GIS platform INPPINS is used to geo reference the existing network details and exported to 1D SWMM model. The model is simulated for extreme flood event occurred in past. The simulation run results identifies overflowing drainage nodes and flood inundation maps and risk maps prepared. The flood risk maps identify the low lying areas which need immediate attention in case of emergency. The overflowing nodes suggest the need of improvement of drainage in the area to safely dispose of the storm water and minimize the flooding.
\end{abstract}

\section{INTRODUCTION}

An urban flood occurs when water overflows sewers, waterways and makes its path into the buildings, backyards, streets and other properties (Zameer et al., 2013). Former studies on flood disasters mainly focused on riverine floods which mainly affects coastal areas and rural areas. In recent scenario flooding in urban areas becomes more common because of increase in incidences of high intensity rainfall in shorter duration of time (Awakimjan, 2015; Westra et al., 2014). Flooding is a natural phenomenon, but human activities has significantly altered natural drainage processes thereby causing greater flood risk (Gupta and Nair, 2011; Prasad 2014). Urbanization results lot of pressure on land use which indorses habitations encroachment towards flood plains and low-lying areas (SOPUF, 2017). Moreover, urbanization leads to decreases in pervious areas which, results into, significant increase in the runoff volume. This excess volume of runoff causes over flowing of storm water drainage systems resulting water spread in adjoining areas. The problem of flooding further persist with encroachment of waterways, inadequate capacity of drains and lack of maintenance. All these results into urban flooding even for moderate precipitation which is why "Urban flooding" is recognized as a disaster significantly different from riverine flooding (Suriya and Mudgal, 2012).
Urban flood as a hazard, defined by (Thieken et al., 2006) is the exceedance probability of the potentially damaging flood situation in a given area with specified period of time. Urban areas are densely populated areas thus there will considerable infrastructure damage and economic loss due loss of business, production and opportunity. Again flooding of streets affects the traffic system and day-to-day life. Figure 1 summarizes the impact of urban floods on society and environment.

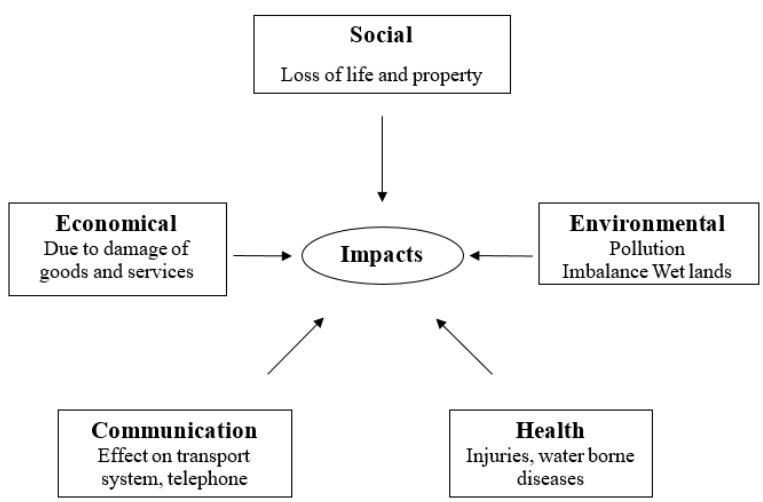

Figure 1: Impacts of Urban floods

* Corresponding author 
Urban floods are not new in India. As a developing county most of the Indian cities are facing urban flood problem. Some of the past major floods in India are Hyderabad-2000, Ahmedabad-2001, Delhi-2002, 2003, 2009, Chennai-2004, Mumbai-2005, Surat-2006, Kolkata-2007, Jamshedpur-2008, Guwahati-2010 and Srinagar-2014 (Rafiq et al., 2016; Rangari et al., 2016). The most recent devastating ones are Chennai2015, Hyderabad-2016 and Kerala-2018.

Avoiding Such events is not promising but hydrologic modeling will help us in understanding of process and develop combat strategies to deal with it. The main aspect of flood modelling is to understand the characteristics of flood in the urban area and its socio-economic aspects. The extent of flood inundation and depth of inundation are considered as the most important flood parameters, especially when it comes to mapping flood hazards (Campana and Tucci, 2001). With the advent of GIS supported hydraulic models it is possible to convert the water surface elevation profile at various output locations into inundation map (Halwatura et al., 2013). The inundation map provides idea about possible areas under risk of flooding during the rainfall events thus early warnings can be set and various structural and non-structural measures can be adopted to reduce the risk. Very few models are available which incorporates the complete topographical information while preparing flood inundation maps. Some of them are FLO-2D, HEC-Geo RAS, PCSWMM, MIKE FLOOD (Maniyar et al., 2015). The effective way of modelling urban floods is to use 2-D mesh for surface flow and 1-D unsteady flood simulation for storm water drains (Chang, Wang \& Chen, 2015). The availability of digital elevation models (DEM) has made the urban flood modelling easy where lesser data is available in case of urban catchments (Magesh et al., 2012). Literature shows assessment of the flood pattern and graphical output can give clear idea of highly affected areas and can help the authorities to produce the scientific action plan (Patel et al., 2017; Kulkarni et al., 2014; Shrestha et al., 2014; Knebl et al., 2005; Tate, 1999).

The present study focuses on recognizing the highly effected areas which are liable to flooding when extreme rainfall occurs for part of Hyderabad city (Zone XIII). A coupled 1D-2D flood modelling approach is used to identify flood prone areas and develop flood inundation and flood risk maps. 1D model for pilot area is developed using storm water management model (SWMM) and coupled with 2D PCSWMM. A web based GIS platform INPPINS is used to geo reference the existing network details and exported to 1D SWMM model. The model is simulated for extreme flood event occurred in past. The simulation run results identifies overflowing drainage nodes and flood inundation maps and risk maps prepared. The flood risk maps categorize the low lying areas which need immediate attention in case of emergency. The overflowing nodes suggest the need of improvement of drainage in the area to safely dispose of the storm water and minimize the flooding.

\section{STUDY AREA AND DATA COLLECTION}

Hyderabad, a vibrant metro city in India and capital of Telangana is facing the problem of urban floods frequently. It is divided into 16 stormwater zones by Greater Hyderabad Municipal Corporation (GHMC). The area selected for present study is Zone XIII. It is one of most severely affected zone of Hyderabad city. The total area of Zone XIII is 75.29 Sq.km. The Zone XIII has eleven sub catchments, 357 junctions and
358 drain conduits. Figure 2 shows the stormwater zone map of Hyderabad city and google map location of Zone III.
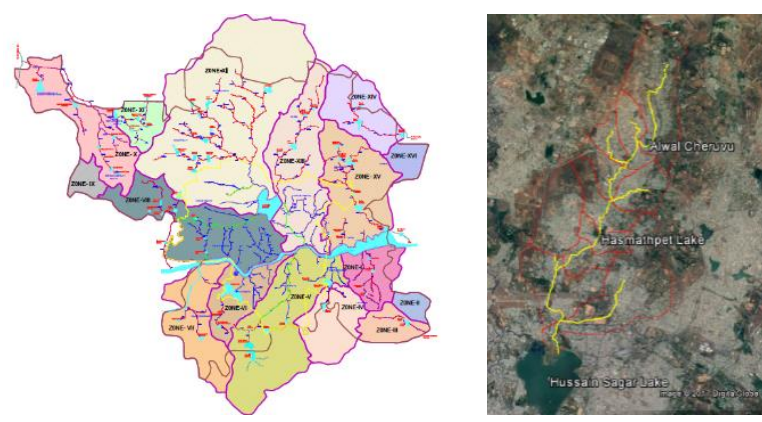

Figure 2: Stormwater zone map of Hyderabad city (left) and google map location of Zone III (right)

The data used to generate the urban flood model obtained from the different sources. The details of sub-catchments, drains and junctions are obtained from the Voyant's Solutions pvt ltd. These data given in the form of Auto CAD drawings and attribute data. The Digital Elevation Model (DEM) obtained from National Remote Sensing Center (NRSC) Hyderabad. The available is Cartosat DEM with 10-meter resolution. The rainfall data is procured from Indian Meteorological Department (IMD) Hyderabad.

\section{METHODOLOGY}

Flooding in urban areas have become a common phenomenon worldwide. Considering the huge losses due to such events, planning and application of suitable prevention methods has gained due importance lately. Knowledge of inundation depths with its areal extent and probable drainage risk junctions will help to take administrate decisions. In past only one dimensional models were used to find the overflowing junctions in drainage network. Such approach gives possible rise of water depth in the flow channel. In urban flood modelling surface flow has equal importance which causes the inundation near drains. The present study presents a coupled 1D-2D modelling approach which can consider both flow in drains and surface flows to find the inundation depths and areas under risk of flooding. A coupled 1D-2D PCSWMM model for Zone XIII of Hyderabad is developed with the help of data available in the form maps and attribute values. Figure 3 shows the flow diagram of PCSWMM 1D-2D model development.

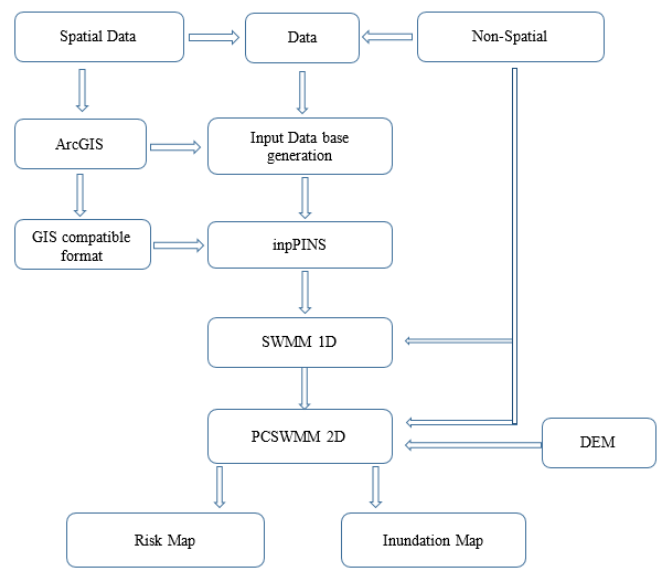

Figure 3: Flow chart of 1D-2D model development (Zone III) 


\subsection{Data Preparation and Parameter Estimation}

The data collected from different sources is converted into Geographic Information Systems (GIS) compatible format using ArcGIS 10.1. The data is available in two forms: spatial and non-spatial format. Spatial data includes Auto CAD drawing and Cartosat Dem of $10 \mathrm{~m}$ Resolution. AutoCAD data is converted to GIS compatible format. The shape files of sub catchments, drains and junctions are extracted from the Auto CAD drawings and are adjusted to generate complete database for Zone XIII watershed using georeferenced Resourcesat-2 L4MX 16Feb2016 image in ArcGIS. The elevation data is extracted from Cartosat Dem. Non spatial data includes details of drain network like depth, width and length of the drain collected from GHMC. Existing $2 \mathrm{~m}$ x $3 \mathrm{~m}$ drain channels are adopted for model development. Length of channels is extracted from shape files in ArcGIS. The database includes data of eleven sub catchments, 358 drains and 357 nodes. Details of sub-catchment is presented in Table 1. Figure 4 shows the Auto CAD drawing georeferenced with Resourcesat-2 L4MX 16Feb2016 image and GIS compatible shape files of Sub catchments, Drain network and junctions developed from it.
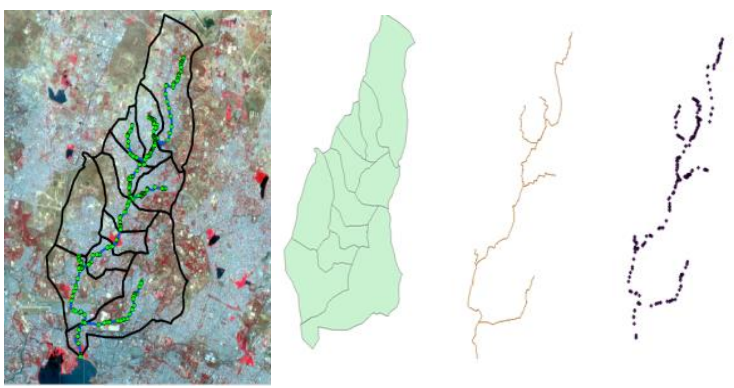

Figure 4: Georeferenced Auto CAD drawing (left) and shape files of Sub catchments, Drain network and junctions (right)

Table 1: Details of sub-catchment

\begin{tabular}{cccc}
\hline Sub_ID & AREA (h) & SLOPE & IMPERV \\
\hline $\mathbf{1}$ & 859.9641 & 5.95 & 22.538 \\
$\mathbf{2}$ & 268.3637 & 6.285 & 79.67 \\
$\mathbf{3}$ & 162.442 & 5.842 & 77.087 \\
$\mathbf{4}$ & 212.1636 & 5.871 & 61.818 \\
$\mathbf{5}$ & 311.0915 & 6.711 & 40.141 \\
$\mathbf{6}$ & 316.6447 & 6.562 & 31.852 \\
$\mathbf{7}$ & 520.5264 & 6.042 & 42.404 \\
$\mathbf{8}$ & 175.1402 & 7.165 & 46.996 \\
$\mathbf{9}$ & 182.2518 & 6.817 & 51.515 \\
$\mathbf{1 0}$ & 589.1484 & 6.165 & 46.078 \\
$\mathbf{1 1}$ & 941.9523 & 8.238 & 41.655 \\
\hline
\end{tabular}

The input parameters require to develop and simulate hydrological model are channel roughness, surface roughness, infiltration data, evaporation and rainfall data. The drainage channels are made of cement concrete. Thus Surface roughness (manning's n) for plain cement concrete surface 0.013 taken from literature (Chow, 1959). The study area mostly contains sandy loam soil. Surface roughness (Manning's $\mathrm{n}$ value for 2D flow area) is selected as 0.025 based on land use data and soil type (sandy loam soil). The model uses Green-Ampt Infiltration method to calculate infiltration. Based on soil type Green-Ampt Infiltration parameters are tabulated in Table 2. Evaporation is almost near to zero and considered as nil because flooding scenario happens in monsoon periods and temperature is very less. Hyderabad has experienced several flood events viz. August 1954, August 1970, August 2000, August 2008 and August 2016. Amongst these August 2000 event was worst calamity in the history of Hyderabad with rainfall magnitude of $312.10 \mathrm{~mm}$. The rain event started on $23^{\text {rd }}$ Aug. 2000 at 2 am and continued to fall for next 31 hours which resulted in flooding situation inundating several parts of city and causing huge property loss. Thus to study the response of Zone XIII catchment in present circumstances to such extreme event August 2000 rainfall is considered to simulate the model (Figure 5).

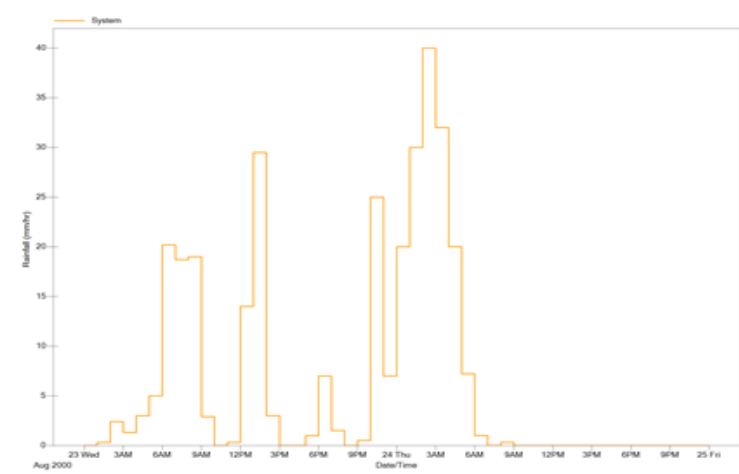

Figure 5: Hyetograph of August 2000 rainfall event

Table 2: Green-Ampt Infiltration parameters

\begin{tabular}{lccc}
\hline \multicolumn{1}{c}{ Texture Class } & $\begin{array}{c}\text { Porosity, } \phi \\
\left(\mathrm{cm}^{3} / \mathrm{cm}\right)\end{array}$ & $\begin{array}{c}\text { Hydraulic } \\
\text { conductivity, } \\
\theta, \text { saturated } \\
(\mathrm{cm} / \mathrm{hr})\end{array}$ & $\begin{array}{l}\text { Wetting front } \\
\text { suction }(\mathrm{cm})\end{array}$ \\
\hline Sand & 0.437 & 21.00 & 10.6 \\
\hline Loamy sand & 0.437 & 6.11 & 14.2 \\
\hline Sandy loam & 0.453 & 2.59 & 22.2 \\
\hline Loam & 0.483 & 1.32 & 31.5 \\
\hline Silt loam & 0.501 & 0.68 & 40.4 \\
\hline Sandy clay loam & 0.398 & 0.43 & 44.9 \\
\hline Clay loam & 0.464 & 0.23 & 44.6 \\
\hline Silty clay loam & 0.471 & 0.15 & 58.1 \\
\hline Sandy clay & 0.430 & 0.12 & 83.6 \\
\hline Silty clay & 0.479 & 0.09 & 64.7 \\
\hline Clay & 0.475 & 0.08 & 71.4 \\
\hline
\end{tabular}

\subsection{Model description}

The flow in channel is calculated by 1D SWMM model developed using SWMM 5.1 while overland flow calculations are done using 2D PCSWMM model. SWMM is not spatially linked thus inpPINS is used to integrate it with GIS.

3.2.1. inpPINS: inpPINS incorporate GIS into 1D Storm Water Management Model (SWMM) so that SWMM visual objects are linked spatially (Pinna et al., 2011). Figure 5 shows the working of inpPINS. The information stored in GIS shape and grid files is used to generate input data file to SWMM and convert SWMM output in the form of GIS shape files that can be combined with DEM. 


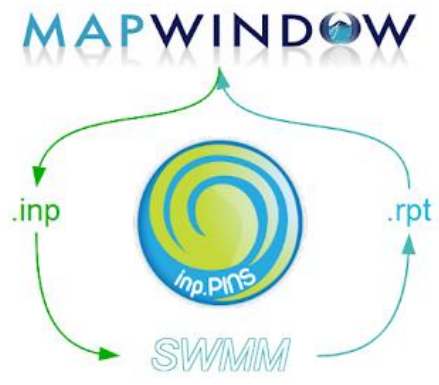

Figure 6: working diagram of inpPINS (https://sites.google.com/site/inppins/guide)

3.2.2. 1D SWMM: Storm water management model (SWMM) is 1 dimensional (1D) model and calculates the flow and depth of flow in flow channels. A 1D SWMM model for the study area is prepared using existing drainage details collected from GHMC. The drainage network shape file prepared in ArcGIS database is used to develop 1D drainage network of study area. The drainage network consists of subcatchments, conduits channels and junction nodes connecting conduits as shown in Figure 6. Channel dimensions and length, channel surface roughness, sub-catchment outlet, infiltration, evaporation and rainfall data are the input parameters for the model simulation. The parameter estimation for model development and simulation is discussed in section 3.1. In SWMM runoff generated by considering each sub catchment as a non-linear reservoir with a single inflow generated from rainfall. The model so prepared is simulated using Dynamic wave routing. This solves the one dimensional Saint Venant flow equations and produces accurate results in SWMM. These equations consist of the continuity and momentum equations for conduits and a volume continuity equation at nodes.

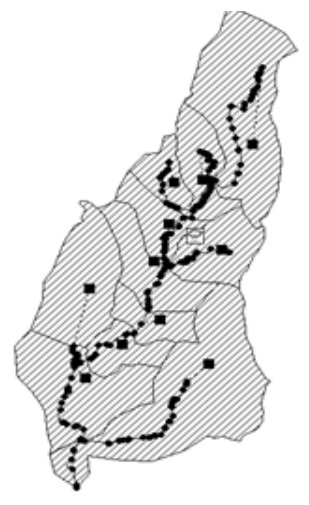

Figure 7: SWMM 1D Model

3.2.3. 2D PCSWMM: To develop $2 \mathrm{D}$ model for the study area inpPINS generated SWMM file is exported to PCSWMM and 2D flow area is delineated to account for overland flow. Cartosat DEM added as background layer to the model to add elevation data and digital terrain surface. The $2 \mathrm{D}$ cells are generated by creating $2 \mathrm{D}$ mesh over $2 \mathrm{D}$ flow area. A 2D node is generated at the center of each 2D cell trough which 2D flow exchange takes place. The DEM layer added in background provides the elevation for 2D cells generated. The parameter required to prepare 2D model are surface roughness, 2D mesh type and size. Both uniform and nonuniform meshes can be prepared but we used uniform hexagonal mesh as there is no river passing through study area and no abrupt elevation changes. A finer $5 \mathrm{~m}$ hexagonal mesh is adopted for present study as $10 \mathrm{~m}$ resolution Cartosat DEM is available. Surface roughness (Manning's n value for 2D flow area) is selected as 0.025 as discussed in section 3.1. Figure 6 shows the PCSWMM 2D model with DEM layer and 2D Mesh created with 2D nodes.
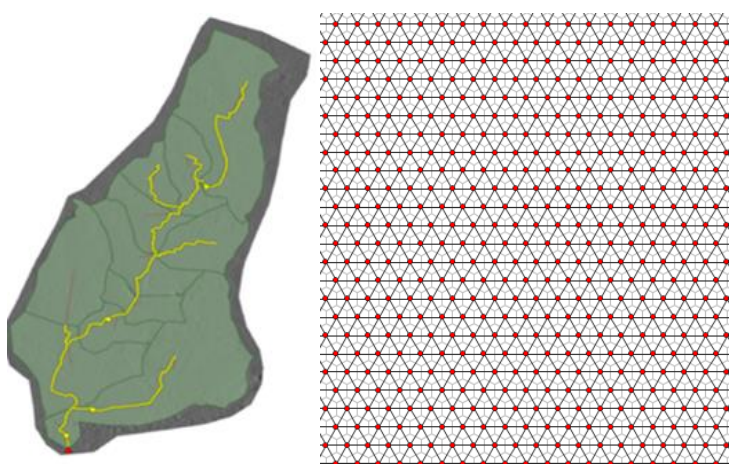

Figure 8: PCSWMM 2D with DEM (left) and model 2D mesh (right)

\section{RESULT AND DISCUSSION}

A coupled 1D-2D model for Zone XIII is developed and simulated for past critical rainfall event of August 2000. The total precipitation over the catchment is $312.10 \mathrm{~mm}$. simulation results shows $95 \%$ of rainfall is converted into surface runoff. Table 3 shows the detailed output summery of 1D SWMM simulation.

Table 3: SWMM output summery

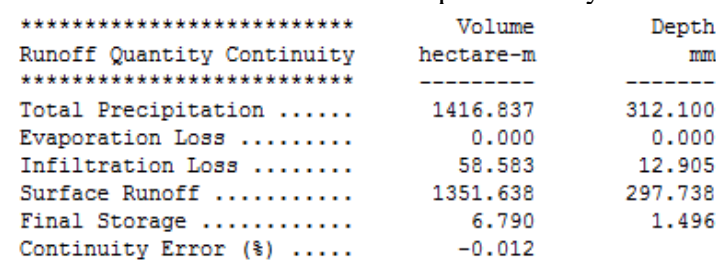

To visualize the results from a $1 \mathrm{D}$ analysis, it is useful to create a risk map of flooding junctions. Risk maps display the flood risk levels for overflowing junction nodes based on userdefined criteria. In the present study two indicators: one duration and other depth is used for identifying the junctions which are at risk of flooding (Table 4).

Table 4: Risk indicators

\begin{tabular}{|c|c|c|c|}
\hline & $0-30$ minutes & $30-60$ minutes & $>120$ minutes \\
\hline$<1$ meter & Low risk & Medium risk & Medium risk \\
\hline $1-1.5$ meter & Medium risk & High risk & High risk \\
\hline$>1.5$ meter & High risk & High risk & High risk \\
\hline
\end{tabular}

The model considers the maximum depth generated at particular junction over the conduit. Thus risk map is generated based on duration and depth of water rise at the junction nodes. The location of flooding nodes shown on google map (Figure 7). The risk analysis shows 133 nodes come under low risk, 97 nodes come under medium risk and 127 nodes come under high risk of flooding (Table 5). 


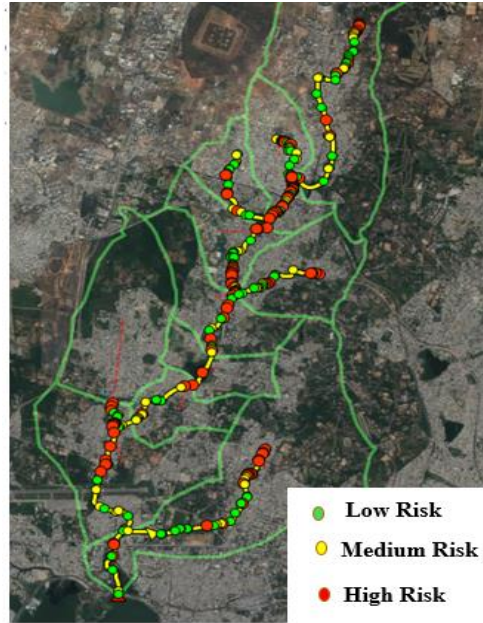

Figure 9: Risk map for junctions

Table 5: Classification of node under different risk

\begin{tabular}{|c|c|c|}
\hline & Risk type & Number of nodes \\
\hline & Low Risk & 133 \\
\hline & Medium Risk & 97 \\
\hline & High Risk & 127 \\
\hline
\end{tabular}

The inundation map helps to understand the areas which has flood effect and depth of water that is possible to reach at these areas. PCSWMM provides interface to couple 1D and 2D models. The 1D model is connected to the 2D mesh. This 2D mesh has $2 \mathrm{D}$ nodes which are connected by rectangular open channels. When the 1D nodes over flow, the excess volume of water reaches the $2 \mathrm{D}$ mesh and routing method followed by Dynamic wave equation to generate the flood inundation. Analysis shows total area of inundation is $748 \mathrm{Ha}$. The flood risk map id developed from flood inundation map based on depth of inundation at particular area. The risk is divided into three classes Low risk, medium risk and high risk Figure 8 shows the flood inundation and flood risk map developed for Zone XIII. Table 6 summarizes the total area under each risk type.
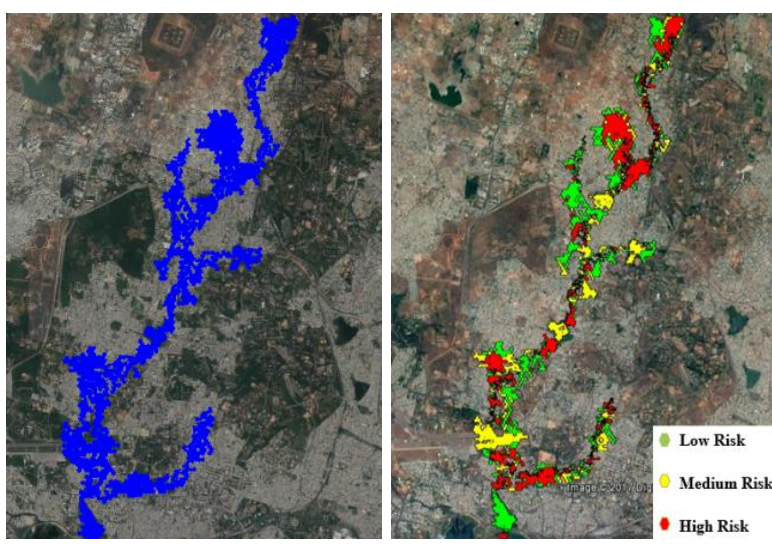

Figure 10: Zone XIII flood inundation map (left) and flood risk map (right)
Table 6: Classification of inundation risk

\begin{tabular}{|c|c|c|c|}
\hline & Risk type & Depth & Area (H) \\
\hline & Low Risk & $<0.5$ meter & 293 \\
\hline & Medium Risk & $0.5-1$ meters & 205 \\
\hline High Risk & $>1$ meter & 250 \\
\hline
\end{tabular}

\section{SUMMARY AND CONCLUSIONS}

Flood inundation modeling has major role in flood mitigation and minimizing its effects. These models provide the predictions of flood extents and inundation depths. This helps in identifying the spatial spread of effected area and risk to life and property can assessed. In present study extreme flood event is simulated for the Zone XIII of Hyderabad city and flood inundation and flood risk maps are developed. From the simulation results, it is observed that northern part of study area is more vulnerable to flooding. The results are exported to google map and it shows the low-lying areas adjacent to the water bodies are under high flood risk. The developments in these low-lying areas are more susceptible to flooding. These areas have been encroached mainly for building residential colonies and often get flooded during heavy rains as water tends to flow and settle in areas which are topographically at lower elevation. The main areas facing inundation problem are Maashantoshi colony, areas near Ramanalacheruvu those are Surya Nagar Colony, Krishna nagar colony, Ayyapanagar colony, Alwal Jyothinagar, Begam pet airport area, Maredapally, Himayat nagar Saraswathi colony these are the areas having high flood risk. The total area effected by the inundation is $748 \mathrm{Ha}$

\section{ACKNOWLEDGEMENT}

This work is supported by the Information Technology Research Academy (ITRA), Government of India under, ITRA-water grant ITRA/15(68)/water/IUFM/01. We thank GHMC and M/S Voyant's Solutions Private Limited, Hyderabad for sharing technical data. We also thank NRSC for high resolution dataset to take the study forward. We also thank to CHI PCSWMM and PCSWMM technical team for their valuable suggestions and technical support.

\section{REFERENCES}

Awakimjan, I., 2015. Urban Flood Modelling Recommendations for Ciudad Del Plata. Bachelor Thesis, University of Twente, Netherland.

Campana, N. A., and Tucci, C. E., 2001. Predicting floods from urban development scenarios: case study of the Dilúvio Basin, Porto Alegre, Brazil. Urban water, 3(1), 113-124.

Chang, T. J., Wang, C. H., and Chen, A. S., 2015. A novel approach to model dynamic flow interactions between storm sewer system and overland surface for different land covers in urban areas. Journal of Hydrology, 524, 662-679.

CHI water development team, 2017. CHI PCSWMM. https://support.chiwater.com/Articles 
Chow, 1959. Manning's $\mathrm{n}$ for Channels http://www.fsl.orst.edu/geowater/FX3/help/8 Hydraulic Ref erence/Mannings $\mathrm{n} \_$Tables.htm

SWMM development team, 2017. EPA SWMM 5.1. https://www.epa.gov/water-research/storm-watermanagement-model-swmm

Gupta, A. K., and Nair, S., 2011. Urban floods in Bangalore and Chennai: risk management challenges and lessons for sustainable urban ecology. Current Science (Bangalore), 100.11 (2011): 1638-1645.

Halwatura, D., and Najim, M. M., 2013. Application of the HEC-HMS model for runoff simulation in a tropical catchment. Environmental Modelling \& Software 46 155-162.

inp.PINS development team, 2016. Creative Commons Attribution-shareAlike3.0

https://sites.google.com/site/inppins/guide.

Kulkarni, A. T., Mohanty, J., Eldho, T. I., Rao, E. P., and Mohan, B. K., 2014. A web GIS based integrated flood assessment modeling tool for coastal urban watersheds. Computers \& Geosciences, 64, 7-14.

Knebl et al. 2005. Regional scale flood modeling using NEXRAD rainfall, GIS, and HEC-HMS/RAS: a case study for the San Antonio River Basin Summer 2002 storm event. Journal of Environmental Management, 75 (2005), 325-336.

SOPUF Ministry of Urban Development, GOI, 2017. Urban flooding standard operating procedure. Government of India. https://amrut.gov.in/writereaddata/SOP _Urbanflooding_5Ma y2017.pdf

Magesh N. S., and Ch N., 2012. A GIS Based Automated Extraction Tool for the Analysis of Basin Morphometry, Bonfring. International Journal of Industrial Engineering and Management Science, 2, Special Issue Special Issue on Geospatial Technology Development in Natural Resource and Disaster Management, 32-35.

Maniyar, F. A., and Bhatt, J. P., 2015. Literature study on hydraulic modelling of floodplain mapping. International Journal of Research in Engineering and Technology, eISSN: 2319-1163.

Prasad, R. K., 2014. Urban Floods- A Review. International Journal of Innovative Research in Science, Engineering and Technology, Volume 5, Special Issue 6, ISSN (Online): 2319 $-8753$.
Patel, P. D., Ramirez, J. A., Srivastava, P. K., Bray, M., and Han, D., 2017. Assessment of flood inundation mapping of Surat city by coupled $1 \mathrm{D} / 2 \mathrm{D}$ hydrodynamic modeling: a case application of the new HEC-RAS 5. Nat Hazards. DOI 10.1007/s11069-017-2956-6.

Pina et al., 2011. Floodplain delineation with Free and Open Source Software. 12th International Conference on Urban Drainage, Porto Alegre/Brazil, 11-16 September 2011.

Rafiq, F., Ahmed, S., Ahmad, S., and Khan, A. A., 2016. Urban floods in India. International Journal of Scientific \& Engineering Research, Volume 7, Issue 1, 721- 734.

Rangari, V. A., Gopi, K. V., Umamahesh, N. V., and Patel, A. K., 2016. Simulation of urban drainage system using disaggregated rainfall data. ICWEES March 15th-18th, 2016 International Conference on Water Environment, Energy \& Society-2016 Organized By Texas A \& M University, USA \& AISECT University, Bhopal, India.

Shrestha, S., Fang, G., Rahman, A., and Aziz, K., 2014 Application of artificial neural networks in regional flood frequency analysis: a case study for Australia. Stochastic Environmental Research and Risk Assessment, Volume 28 , Issue 3, pp 541-554.

Suriya, S., and Mudgal, B. V., 2012. Impact of urbanization on flooding: The Thirusoolam sub watershed - A case study. Journal of Hydrology, 412-413, 210-219.

Thieken, A., Merz, B., Kreibich, H., and Apel, H., 2006. Methods for flood risk assessment: Concepts and challenges. In international workshop on flash floods in urban areas, Muscat, Sultanate of Oman.

Tate E., 1999. Floodplain mapping using HEC-RAS and ArcView GIS. CRWR Online Report 99-1.

https://www.ce.utexas.edu/centers/crwr/reports/online.html.

Voyant's Solutions Pvt. Ltd

https://www.voyants.in

Westra, S., Fowler, H. J., Evans, J. P., Alexander, L., Berg, V. P., Johnson, F., Kendon, E. J., Lenderink, G., and Roberts, N. M., 2014. Future changes to the intensity and frequency of short-duration extreme rainfall. An AGU Journal Review of Geophysics, Volume52, Issue3 Pages 522-555. https://doi.org/10.1002/2014RG000464

Zameer, A., Rao, R. M., and Reddy, K., 2013. Urban floodingcase study of Hyderabad, Global Journal of Engineering Design and Technology, Vol.2(4):63-66. 